\title{
Cooperation and competition: missions, the colonial state and constructing a health system in colonial Tanganyika
}

\author{
Michael Jennings
}

Patchy, incomplete and of varying quality over time and place: nonetheless, since the late nineteenth century, missions and other faithbased organisations and religious institutions have been central to meeting the welfare needs of Africans across the continent, a critical component of what we might consider the public-private mix of public goods provision. As Anna Greenwood reminds us in the Introduction to this volume, 'colonial medicine' in Tanganyika (as with other colonies and imperial possessions) was never, and never could have been, solely provided by any one actor. The Colonial Service was neither unified nor unidirectional in its provision, and collaboration between the Colonial Medical Service and non-state actors was the norm. In Tanganyika by the 1930s, the claim to be at least attempting to meet the health needs of the territory could only really be justified (to the extent that it could) by recognising the voluntary role that actors in the form of missionary organisations were playing in running health services for Tanganyikans.

The model that characterised late colonial-period Tanganyika was one of public-private partnership. Having long acted as informally contracted health providers, by the mid-1940s missions became formal partners in the delivery of healthcare. In return for accepting greater government oversight of mission facilities and a requirement to meet state-set standards and targets, missionary medicine was to be financially supported by the colonial state and granted privileged access to policy-making and policy-setting structures.

As Greenwood notes in the Introduction, such collaboration between colonial state and non-state partners usually reflected colonial selfinterest, and the model that had emerged by the mid-1940s certainly did that. But it also reflected internal dialogues within and between mission medical providers as to their wider social role. In other words, the public-private (voluntary) partnership that was established 
reflected the coming together of two sets of strategic interests: those of the colonial state, certainly, but also those of mission medical providers. Moreover, the process of integration was one in which both missions and the administration engaged in, fought over and negotiated the final settlement in a way that confirmed the strengths and weaknesses that both possessed in seeking to establish control over that process.

But for anyone looking ahead in the early twentieth century, the emergence of this particular public-private mix of service provision, and the dominant role played in it today by faith-based organisations, would have appeared unlikely. How had missions, initially atomised and jealous of their independence (and regarded as such by the colonial state), come to formally partner the colonial state in providing welfare and social services that embraced education and health? This chapter argues that essential to that process was the emergence from the 1930s of a conception of a 'mission sector' which emerged within both missionary organisations and the colonial state, with implications for both that would last beyond the end of the colonial period in the country.

This chapter explores some of the dynamics between medical missions in colonial Tanganyika and the colonial medical department. Christian missions did not represent the only religion to be involved in healthcare, but their relationship with the colonial state and their status as major providers of health services created a space which they could legitimately use to create a politicised and engaged faith sector, capable of making demands upon the colonial government. Debates over the level of support that the state should provide for mission health services, conflict over specifics of policy and fears of government plans to establish formal control over medical missions helped to shape the emerging faith sector and the interaction between voluntary and public arenas.

\section{Reinserting the place of the mission into colonial medicine in Tanganyika}

Despite the growing literature on missionary healthcare, there persists a sense in much of it that missionary medicine is somehow different, separate from that of the colonial state. If not exactly written out of the historical narrative of healthcare in Tanzania, missionary medicine has been presented by some as an evolutionary dead end, making a minimal impact on the shape and structure of post-colonial biomedical services. David Clyde's official History of the Medical Services of Tanganyika, for example, written for the new government following independence, excluded the contribution made by mission medical services from any significant discussion. The 1964 Titmuss Report similarly rejected 
missionary medicine as an important factor in the evolution of the country's health services, noting, 'outside a very small circle these early endeavours by voluntary agencies made little impression on the health or health practices of the African population'. The real history of European healthcare began, the report noted, 'in 1888 with the period of German administration'. ${ }^{1}$ Even Meredeth Turshen's account of colonial medicine in Songea District in southern Tanganyika similarly makes little reference to the mission hospitals, clinics and the doctors working there, seeing medicine and health services in the district as being determined by colonial state economic, social and political objectives. Where missions do appear in Turshen's account, they are as adjuncts to and collaborators with the colonial state. No differences are seen between the colonial state and mission priorities, ideological drivers and objectives. ${ }^{2}$ The term 'colonial medicine' is used here very much as shorthand for colonial state medicine.

In reducing missionary medicine to either willing collaborator in the colonial vision of the occupying state or aloof outsider operating through a heady mix of physick and metaphysics, such accounts fail to capture both the realities of missionary medicine and the nature of colonial medicine in Tanganyika.

Colonial medicine, in the sense of European biomedical services within the colonial setting, was never the sole remit of the colonial state. For much of the colonial period, the landscape of European medicine as practised in Tanganyika, as in British colonial Africa more widely, was far more varied. It was a fragmented, disparate mixture of public (colonial state and services offered through the Native Authorities), private (individual private practice and health services run and paid for by commercial concerns) and private-voluntary (organisations providing services for both humanitarian and more metaphysical reasons). In terms of numbers, the state was never overwhelmingly dominant. Indeed, until the mid-1930s, and considerably later in some remote and rural areas of sub-Saharan Africa, missions remained dominant actors in healthcare provision; whilst in some countries private company services had exclusive responsibility over large swathes of territory.

The extent to which any particular sector (state, private, voluntary) dominated across time and between colonies varied. In French Africa, for example, the state loomed large as the ultimate source of social welfare for Africans. In colonial territories with significant commercial concerns (plantations, mines and other large-scale industrial activity), private practices for workers and worker families played a greater role. But in much of sub-Saharan Africa, with some notable exceptions, missions were significant providers of healthcare services for Africans throughout the colonial period, often having established themselves 
as such before even colonial boundaries had been set and the violent occupation by the colonial state had begun. This was the case in Tanganyika. Writing of one area in southern Tanganyika, missionowned and run 'clinics and hospitals provided', Terence Ranger notes, 'the sole effective medical facilities in Masasi district' ${ }^{3}$ The same could be said for many predominantly rural and often remote areas across Tanganyika and British colonial Africa more widely.

Nor were mission services simply filling in the gaps in colonial Tanganyika, as some accounts imply. Even before the emergence in the 1930s of an evolution towards a public-private partnership in the delivery of health (in which missionary services were formally incorporated into official welfare structures), mission medical services were regarded (even if not officially) as vital partners in making biomedical health services available to Tanganyikans.

Moreover, the transition to this formal partnership was more than a reaction on the part of missions to government policy, but reflective of internal parallel processes on the part of those missionary organisations. Certainly, as David Hardiman has written 'colonial medical departments became more interventionist, and more began to be spent on medicine'. But his assertion that '[i]n the process, they began to intrude on what had been regarded before as mission territory ${ }^{4}$ misses the extent to which missions proactively engaged in shaping the new structures and systems that emerged in this period in Tanganyika. This was no simple intrusion of the state into mission territory, but the defining of a new space in which both state and voluntary agencies co-existed. For missions had similarly undergone a process of reorganisation and redefinition of their relationship with the state, creating what in effect transformed disparate, individualised medical mission services into a more organised and coordinated (in policy terms at least) 'faith health sector'. Moreover, far from seeing post-war government expansion in the medical sector as an encroachment into their territory, mission policy - as expressed through the institutions established to represent this 'sector' - had been calling for greater synergy between mission and state services since the 1930s. Differences emerged over policy specifics and particular directions, but missions actively embraced a closer relationship with, and formal inclusion in, colonial state public health provision - before, even, the colonial state adopted such a position.

\section{Speaking with one voice: creating the 'mission sector'}

Even before German occupation and the establishment of the colonial state from the 1880s, missions had long established a presence 
in the territory. They provided healthcare and primary education; they offered training of adults in specific skills; provided (during the pre-colonial period) relief in times of famine, and refuge in times of conflict between the various political and ethnic groups existing in the region. From their first tentative steps in establishing a permanent presence, missions had gradually expanded their activities to include a range of welfare and social services. In the education sector, missions dominated activity throughout the colonial period. Whilst the mission was never the overwhelmingly dominant provider of health services to Tanganyikans, nevertheless, it made significant contributions in wider colonial healthcare too. From the very start, missions were far more than just the sites of Christianity, commerce and civilisation that the Livingstonean and Victorian imaginations of missionary enterprise had envisaged. But if by the 1910s and 1920s they had become, in effect, part of the mix of service providers, they could not be said to constitute a 'sector' in the sense of a collective identity, shared values and objectives and common interests. Reflecting the history of the expansion of missions in Tanganyika, spreading out from the littoral in the second half of the nineteenth century, mission stations remained isolated from one another. Lacking a single forum in which they could pool experiences and aspirations, belonging to different faith traditions and coming from a range of European and North American countries, missions operated as the largely individual, atomised units they were, competing rather than cooperating with their fellow faith adherents.

If missions faced few internal pressures to represent a more united front, there was also little encouragement from the colonial state itself. The administration remained determined to maintain strict control over policy and funding decisions, and consequently was reluctant to dilute such control through closer partnerships with non-state providers. True, the colonial state accepted the reality of mission-dominated primary school provision, albeit under government supervision and control. But as Ana Madeira writes in relation to the Belgian Congo:

The missionary zeal in promoting vocational education was thus seen by the State as a practical economic investment in the sense that convergent ideology and consistent practice were saving the central government the trouble of having to spend a considerable part of the budget on financing education in the colonies. ${ }^{5}$

So too in Tanganyika, where, in 1925, at a conference called by Governor Cameron to discuss welfare services in Tanganyika, it was agreed that the colonial state would fund mission-run education services, in return for taking overall control of education policy and standards. And it did 
financially support mission medical services, albeit in a (deliberately) ad hoc fashion. Unlike its relationship with the education services, the Tanganyikan administration did claim to be the main provider of medical services in the territory, suggesting (rather spuriously) that its model of 'preventive' medicine was of greater value than the curative services offered by missions. ${ }^{6}$

Thus, if missions did not speak with one voice, nor did the government seek to work with missions as a 'sector'. As a result, despite missions making a considerable contribution to social welfare provision in colonial Tanganyika, there existed no recognisable 'non-state' sector pursuing common goals and agendas, sharing information and presenting a unified front to the government. The mission influence could not be ignored by the colonial state, but its lack of cohesion meant that in reality it held little influence over medical policy debates and discussions. By the 1930s, however, the pretence that the colonial state was the primary healthcare deliverer was becoming harder to sustain. The mission contribution in this area, fragmented as it was, was nonetheless critical in any claim to be meeting the welfare obligations of colonial rule under the Trusteeship mandate. Even where government hospitals were situated close to mission hospitals, the two often worked to complement, rather than compete with, each other. The Church Missionary Society hospital in Mpwapwa, for example, treated mainly women and children, whilst the government hospital treated men. ${ }^{7}$ The state had effectively conceded maternal and child healthcare services to the missions, recognising the amount of work missions were doing in this area, as well as the innovation and appeal of such services in the areas in which they were situated. ${ }^{8}$

The scale of medical work undertaken by missions belied the colonial administration's claims that it alone was working to address the provision of biomedical healthcare in Tanganyika. In Shinyanga District, the government-run hospital and two government dispensaries treated 4,159 out-patients and 663 in-patients in 1926. The Africa Inland Mission hospital at Kola Ndoto, under the charge of Dr Maynard, treated 26,062 out-patients and 360 in-patients in the same year.' '[T]he major portion of the medical work' in Shinyanga, the District Commissioner noted, 'is being undertaken by Dr Maynard as a purely charitable work. ${ }^{\prime 10}$ In 1931, Dr Maynard and her medical team treated a staggering 69,826 out-patients, and attended 1,322 births in the Native Administration Maternity Home. ${ }^{11}$ The Universities Mission to Central Africa (UMCA) saw 187,271 out-patients in its hospitals and dispensaries in Masasi and Zanzibar Diocese in 1936. ${ }^{12}$ Even at the end of the colonial period, missions were making a substantial contribution: some 6,599,608 out-patients were treated at government 
hospitals and dispensaries in 1959; mission medical services treated $4,518,346 .{ }^{13}$

By the mid-1930s it was becoming clear to both government and mission leaders that the informal, personal linkages on which they relied for communication and cooperation were insufficient for the effective planning and delivery of key services. The lack of formal channels also prevented the easy articulation of a 'mission position', agreed to amongst mission representatives and reflecting common concerns, in relation to the major issue facing mission providers of healthcare services. From the perspective of the state, whilst this limited challenges to its policies from one of the few areas from which a strong and sustained challenge could have emerged, it also hampered government efforts to coordinate and work with missions when it could advantage the state to do so. The government survey of medical missions in 1936 in part reflected a growing awareness that the mission contribution was too significant to ignore. But missions had also grown more aware of the commonalities that bound them together as a group: a shared ethos and character, facing similar constraints and opportunities. In Tanganyika, mission leaders began the process of establishing more formal networks between missions, across denominational lines, in a concerted effort to increase the influence of the mission sector within the colonial state. The 1926 Le Zoute conference on the 'Christian Mission in Africa' had recommended the establishment of an international advisory board to 'assist the cooperation of medical missions with Governments': colonial states could, the conference avowed, 'count upon the missionary societies rendering all possible assistance to Governments in the forwarding of any particular measures of Public Health which it is desirable should be carried out ${ }^{\prime} .{ }^{14}$ However, it was not until almost a decade later that such international mission policy was translated into meaningful practice in Tanganyika.

In 1932 the UMCA Bishop of Masasi wrote to all mission leaders in Tanganyika, expressing concern that efforts by government to work more closely with missions were being hampered by the lack of a clear 'mission perspective' on key policy issues. Mission views were 'so varied as to appear bewildering', he wrote, 'and the desire to give sympathetic support yields to disheartenment. The impression given is that we Missionaries do not know clearly what we do want. ${ }^{15}$ The remedy, Bishop Lucas suggested, was to establish a single organisation representing the mission sector, to enable 'common counsel' with the aim of 'attaining a common policy' to present to government. ${ }^{16}$ In 1934, the Tanganyika Mission Council (TMC) was established as the fulfilment of these ambitions. Its membership consisted of the main Protestant missions working in Tanganyika, thereby frustrating efforts 
to create a truly pan-mission representative organisation. The Roman Catholic Church had declined to participate, perhaps suspicious of a modernising instinct that it detected amongst the proposers of the idea, and already possessing a single organisational structure from which it could negotiate with the state on behalf of all its constituent members. It did, however, agree to participate on an informal basis. ${ }^{17}$

The creation of the TMC, which in 1949 would be renamed the Christian Council of Tanganyika (CCT), marked a new departure both for mission history in Tanganyika and for the history of welfare service provision in the country. It created a distinct mission 'sector', capable of speaking for a large number of missionary organisations operating in the country, negotiating and working with the colonial state as a sector rather than as disparate, individualised organisations. It marked the beginnings of what can be seen as the formal voluntary sector in Tanganyika. ${ }^{18}$ By 1948 TMC membership included the following organisations ${ }^{19}$ :

- Africa Inland Mission

- Augustana Lutheran Mission

- Church of Sweden

- Church Missionary Society

- Elim Missionary Society

- Mennonite Mission

- Moravian Mission

- Swedish Evangelical Mission

- Universities Mission to Central Africa.

The TMC was established as the broad representative organisation for all mission interests, including (but not confined to) mission engagement in social service provision. Meetings between government and the TMC thus included discussions on health and education, what missions could (and should) be doing and questions of how they were to be financially supported, alongside discussions on wider governmentmission relations. In 1936, the Medical Missionary Committee (MMC) was established as a sub-committee of the TMC with a specific mandate to bring about 'closer cooperation between medical missionaries and the Medical Department of the Government' ${ }^{20}$ As a result, it became the main point of contact between the colonial state and missions for the discussion of missionary and colonial state medical services. The first meeting of the MMC, in July of that year, discussed 'the question of the relationship between the Medical Department of the Missions and the Government Medical Services'. ${ }^{21}$ In return for being recognised as a formal partner in Tanganyika's healthcare 
service provision, missions might accept greater oversight from the state's Medical Department, providing reports, cooperating in training and accepting regulation of standards. ${ }^{22}$ The impression given from the start was of a sector that saw itself, and wanted to be recognised, as an integral part of the territory's health services. MMC membership in 1937 comprised: ${ }^{23}$

- Augustana Lutheran Mission

- Bethel Mission

- Berlin Mission

- Church Missionary Society

- Leipzig Mission

- Moravian Mission

- UMCA.

The same year that the MMC was established, the colonial administration sought to better understand what scale of medical mission activity was being undertaken in Tanganyika. It called for data relating to inand out-patients treated. The snapshot provided to the administration demonstrated just how much missions were doing (see Table 1). It was also recognition on the part of the administration that missions were undertaking medical work on a large scale. It was a scale of activity that was to grow over the next 25 years.

In 1951, the MMC, still a sub-committee of the newly renamed TMC (now called the Christian Council of Tanganyika), further institutionalised its function as the principal representative organisation of mission health services with a new constitution. To ensure that it spoke for the whole of the membership the MMC was to be open to all medical practitioners working within the mission sector. The heads of any mission with a medical service were to be invited to all discussions of medical policy, and minutes would be sent to all heads of missions with at least one medical practitioner. ${ }^{24}$ Such measures helped to entrench the MMC as the legitimate and, more importantly, sole voice of medical mission. The following year, in recognition that the role of the MMC had grown beyond the original Protestant mission membership, the organisation was renamed the Medical Mission Advisory Committee (MMAC), henceforth to act as the 'representative of all Mission Medical opinion in Tanganyika, and should in that capacity be consulted and should advise on matters of Government policy affecting Mission Medical work', operating independently from the organisational structures of the CCT. ${ }^{25}$

At the national level, the efforts to create a more unified mission response were broadly welcomed by all missions. The MMC was 


\section{BEYOND THE STATE}

Table 1 Summary of medical missionary work in 1936 for selected Protestant missions *

\begin{tabular}{lclc}
\hline Mission & Out-patients & Hospitals & Dispensaries \\
\hline $\begin{array}{l}\text { Augustana Lutheran Mission, } \\
\quad \text { Kiomboi }\end{array}$ & 88,770 & 2 & 3 \\
Bethel Mission, Bukoba & 14,100 & 2 & 5 \\
Moravian Mission, Tabora & 11,500 & 1 & 3 \\
Leipzig Lutheran Mission & 49,956 & 1 & 6 \\
Church Missionary Society & 93,873 & - & - \\
UMCA (Masasi Diocese) & 26,344 & 2 main & 2 \\
UMCA (Zanzibar Diocese) & 160,927 & 3 small & $10^{+}$ \\
& & 2 maternity & \\
\hline
\end{tabular}

Notes

* Mission figures taken from summaries of medical mission work provided to Medical Department; Church Missionary Society: TNA 450692 v.1 'Medical Work in the Diocese of Central Tanganyika', to Medical Department, 13 October 1936; UMCA, 'The Medical Work of the UMCA in Masasi Diocese. The returns cover statistics from 1935, or the year to mid-1936. Government figures taken from Government of Tanzania, Annual Report of the Medical Department, 1945, Dar es Salaam:

Government printer, 1947, p. 24

† In addition to its 10 dispensaries, the UMCA had 8 'district dispensaries' for which figures for out-patients have not been provided. In 1936 government medical services treated 598,016 out-patients.

focused on key areas of welfare delivery - especially education and health, where constraints and opportunities were similar for the majority of missions - and did not seek to broaden its ecumenical approach to matters theological or spiritual. Efforts to create umbrella organisations for coordinating mission activity at the international level in the post-war period were, perhaps inevitably, more controversial, especially within the Protestant faith. The World Council of Churches (WCC), in its broadly (and inevitably, given the range of churches it sought accommodate) ecumenical approach was regarded by some on the more evangelical wing with suspicion, or even outright disdain. W.O.H. Garman, President of the American Council of Christian Churches (ACCC), denounced the emergence of the WCC as one of the 'forces of antiChrist' for its attempt 'to gain a totalitarian and monopolistic control of the missionary situation throughout the world'. ${ }^{26}$ John Mackay, President of the International Missionary Council, was attacked by Garman for his alleged links to 'communist-front organisations' and his presence at a meeting where delegates 'prayed to the Virgin Mary, a host of saints, and for the dead'. ${ }^{27}$ Yet within Tanganyika, organisations 
which would refuse to join the WCC on religious grounds nevertheless worked with organisations such as the TMC which functioned in similar ways to the WCC, albeit at the national level. The Africa Inland Mission, for example, was a member of the Christian Council of Tanganyika, whilst remaining (in the early 1950s at least) wary of the WCC. Indeed, Reverend Maynard, the long-standing missionary at Kola Ndoto (and whose wife had been one of Tanganyika's most influential and significant mission doctors), wrote to the General-Secretary of the Africa Inland Mission (AIM) criticising views such as Garman's as not only being wrong but potentially undermining mission activity in East Africa. ${ }^{28}$

In bringing together mission medical practitioners from different (Protestant) churches to formulate common positions, the MMC (and from 1952 the ecumenical MMAC) created in the mission medical sphere an identity that transcended (but did not replace) individual mission identities, just as the TMC did for broader (Protestant) mission identity. In sharing experiences and problems, mission doctors and nurses identified cross-denominational constraints, challenges, opportunities and potential threats. The existence of the MMC served to entrench the picture of a sector meeting the health needs of Africans. A single mission might have few hospital beds or practitioners. But working alongside their co-religionists under the MMC, they formed a health sector that rivalled that of the state in its reach. For medical missionary work, it was perhaps less the chance to work with government than the potential to challenge its policies as they affected medical mission services that presented the real opportunity for a new faith sector to flex its muscles and demonstrate its strength through unity.

\section{'Political implications': cooperation and competition between the MMC and the colonial state}

If the primary impetus for the establishment of the TMC and MMC as the voice of the mission sector came from mission leaders themselves, the colonial administration was broadly supportive of these efforts, seeing in them an initiative that could enhance government-mission relations. ${ }^{29}$ However, whilst recognising the possibilities for more coordinated efforts, and for a more effective utilisation of mission capacity, it was reluctant to see the TMC evolve into an organisation with real power over the policy-making process. Missions could inform government of their views, but were to be excluded from access to influence:

Government's present concern was mainly with the educational work of the various missions and the need for its coordination with the State 
enterprise. The Educational Advisory Committee should achieve this purpose provided it was properly and authoritatively informed of the views of the missionary organisations. ${ }^{30}$

For the government, the principal benefit of the TMC was to formulate a coherent mission sector voice, enabling the government to work with a single organisation rather than face the cumbersome task of dealing with each individual missionary society in turn. Moreover, it saw the main area of engagement as the education sector, rather than the medical one. Missions were to be neither encouraged nor expected to take on a more proactive role in shaping colonial policy in the social services.

Meetings of the MMC, attended by the Director of Medical Services (DMS) and other medical officers, were opportunities to press for changes to policy, clarification and support. Greater cooperation and coordination with government was seen as an important area. At a meeting in September 1937 the MMC requested that government inform missions of its plans for constructing hospitals and dispensaries, in order to avoid 'overlapping in work which resulted in wasted effort and in some cases financial losses to Missions'. The meeting also offered advice to the DMS on what the MMC perceived as failures in Medical Department policy. The practice of using unmarried young women as midwives, it advised, was counterproductive, and mission practices of using older, married mothers were more culturally acceptable. The perennial question of the relationship with Native Authority health services was addressed, in this instance whether mission medical practitioners had the right to step in when they noted bad practice (the answer was 'no'). The MMC asked the DMS to permit nurses to handle limited quantities of 'dangerous drugs' where no physician was resident (agreed, subject to notification to government). The DMS also agreed to raise the question of rail freight charges for essential medicines and medical equipment with the railways (although he did not have the power himself to enforce changes in policy). ${ }^{31}$ The following year, at a meeting between missionary representatives (including Catholic) and the Medical Department, the agenda covered methylated spirit regulations; fees charged by mission dispensaries; rail freight charges; dental practice; leprosy control; and efforts against hookworm. ${ }^{32}$ Whilst such meetings allowed missions to raise concerns, the government seemed to view them more as information-gathering sessions than as opportunities to seriously change policies in the light of mission recommendations. Nevertheless, the colonial medical department was keen to find solutions and compromises where possible. The meeting of 1937, for example, requested a change in the law to allow mission 
dispensers and dressers to charge fees without breaking the law: such fees were to the mission, not the individual, and were payments for drugs and dressings administered, not consultation or advice (which was free of charge). The DMS was adamant that the law could not be amended. However, he remained 'sympathetic towards the charging of fees where it is made quite clear that proper attention is being given for free'. ${ }^{33}$ In respect of high freight charges for drugs and equipment, the DMS advised missions to forward him details of discrepancies and high charges for particular items, promising that he would liaise with the railways department. The DMS also agreed to inform the MMC of government plans to open or close dispensaries, in order to better coordinate with mission provision. ${ }^{34}$

Where missions had a particularly dominant role to play, such as in the treatment and care for leprosy sufferers, government was even more careful to involve the MMC in an advisory capacity. Following the publication of a report on Tanganyika's leprosy services, missions 'will be given opportunity for discussion of these recommendations and consultation with Government', the Chief Secretary assured the MMC in $1948 .{ }^{35}$ As part of the 1952 review of government policy towards medical mission, the MMC was asked for 'suggestions' as to future cooperation. ${ }^{36}$

If 'cooperation' was the potential gain to be made from working with a single mission representative organisation, maintaining exclusive control over policy discussion and formulation became, inevitably, the chief site of conflict between TMC/MMC and the colonial state. Whilst it welcomed the desire of missions to work more closely with it, the Tanganyikan administration remained cautious of moving too far in formalising such a role. 'The Government appreciates the importance of securing the widest cooperation of all who are interested in the ... social services', the Chief Secretary wrote in 1944 in a letter to the Secretary of the TMC, 'and will gladly avail itself of opportunities for suggesting such participation as they arise. ${ }^{137}$ But such cooperation was to remain ad hoc, with a barely disguised resistance to any formalisation of procedures:

The Government has taken full note of the recommendation made that wherever practicable and possible the Missions should be allowed to take part in planning social services developments in the Territory, and hopes to be able to act upon it from time to time as suitable occasions arise. $^{38}$

But such caution increasingly cut across the realities of the critical role played by missions in healthcare provision. By 1950, the Medical Department had agreed that the MMC should be formally 
recognised by the department, which should also attend MMC committee meetings to 'discuss matters of common interest' ${ }^{39}$ Notably, despite this, no formal invitation was extended at this moment to the MMC to attend, as an official member, discussions within the Medical Department.

By 1948, however, the colonial administration had already ceded a major concession to the missions in the form of extending grants-in-aid for mission services from education to the medical sector. Until the late 1930s, the government made no regular payments for mission medical services. Missions applied each year, with no guarantee of future commitment, for the limited money paid out by the state to voluntary sector health services. In 1936, the colonial state made relatively small grants totalling $£ 4,309$ (out of a total budget of $£ 185,735$ ) to medical missions: $£ 1,644$ for the maintenance of leprosy camps; £1,356 for Lutindi Mental Hospital, run by the UMCA; £971 for mission maternal and child health services; £319 for drugs (including drugs for leprosy treatment); and $£ 19$ to cover mission assistance in 'epidemic outbreaks' ${ }^{40}$ Fearing that 'the grant of assistance directly from [government] funds to one mission is likely to lead to demands from others', the state avoided creating what it felt would result in a 'more or less unlimited obligation' by refusing to move to a formal grants-in-aid policy as it had done for education. ${ }^{41}$ Indeed, the government feared that one major motivation behind the establishment of the MMC was precisely to lobby for such an obligation. The push towards 'closer cooperation between medical missionaries and the medical department', the DMS noted in 1937, was 'largely a financial question'. Moreover, the DMS noted, there were also 'political implications'. ${ }^{42}$ The MMC was seeking not only to increase government financial commitments to mission facilities but also to 'make recommendations as to grants' ${ }^{43}$

Despite government reluctance to countenance such a development, the increased presence of missionary medical services as a distinct sector, better highlighting the contribution made by missions to healthcare in Tanganyika, made the move towards grants-in-aid for medical missions increasingly difficult to resist. As early as 1933 the government had conceded its willingness to 'consider sympathetically applications for assistance in special lines of work having a direct bearing on public health, such as maternity and child welfare, anti-venereal diseases, and yaws work, leprosy and hookworm and the like' ${ }^{44}$ Four years later, the DMS suggested that in places where there was no colonial medical officer, '[f]ormal agreements might be entered into and scales of remuneration laid down' where missions agreed to undertake work that would otherwise have been done by a state physician. ${ }^{45}$

Given this history of increasing agitation for closer formal ties, it is 
not surprising that the plans for post-war medical development in 1943 recognised the mission sector as playing a critical role:

to the extent that medical missionary effort may comply with such standards as may be determined from the standards set for the Government and Native Authority medical services, as well as the training of medical and nursing auxiliaries and other trained subordinates; to that extent such effort should be state-aided. ${ }^{46}$

In return for greater regulation of mission medical services, and commitments that such services would treat all, regardless of faith (and in effect become a core part of the embryonic national health system), it was agreed that missions would receive regular grants-in-aid in support of their work. The proposals were formalised in the Medical (Grantsin-Aid to Missions) Regulations of 1948, and the Medical (Training Grants-in-Aid to Missions) Regulations that were published the following year in Tanganyika. In 1956, some twenty years after missions had shared a $£ 4,309$ state contribution to their efforts, grants-in-aid to mission medical services (including payments for staff, hospitals and training) amounted to £101,013. ${ }^{47}$

If having ceded the principle of direct government funding for mission services left the state, by the end of the 1940s, believing that it had gone far enough in accommodating mission demands, the question of influence was not yet finished for the MMC/MMAC. Tensions over exactly how much power medical mission should have in framing colonial medical policy were brought to a head in the discussions over the creation of the MMAC in 1952. The MMC presented a robust conception of the role the new organisation ought to play in relation to medical policy within Tanganyika, seeing the institution's remit as being 'to assist in administration of the Grant in Aid regulations, and to advise the Director of Medical Services on all matters related to or affecting the medical work of Missions in the Territory' ${ }^{48}$ For the administration, this was presumptuous. The idea that 'regulations, as approved by Executive Council, should be referred back to this Committee for their further consideration', B. Leechman, the member for social services wrote, 'is out of the question'. ${ }^{49}$ The government was determined that power should remain within the Medical Department alone. 'While it is to be expected that you will most certainly consult this Advisory Committee', Leechman wrote to the DMS, 'I think it most desirable to do nothing to suggest that there is an obligation upon you to seek advice or, most particularly, that it is necessary to act in accordance with that advice. ${ }^{50}$ The DMS similarly regarded such a committee as a challenge to the authority of the government to direct grants-in-aid policy without reference to other actors, writing: 
I do not quite understand what Miss Phillips means when she asks that the Committee should be set up early in order to discuss the future administration of grants-in-aid. If she means merely to discuss the administration of these grants within the framework of the Regulations which have been passed on the Executive Council's agreed policy, then I have no objection; but if she wishes at this juncture to have a meeting to discuss change of policy, I do not think there is much to be gained in doing so. ${ }^{51}$

However, while the higher echelons of the colonial administration were appalled by the idea of granting such privileged access to voluntary non-state actors, the Medical Department itself was more realistic about the need for a flexible approach. The DMS agreed that the new advisory body should be 'consultative', stating that whilst 'ultimate discretion lies with the Director of Medical Services', ${ }^{52}$ he nevertheless recognised the importance of maintaining good links with the mission sector. 'I anticipate needless trouble if all reference is excluded [to such a mission role], and I would deprecate any step likely to affect adversely our relationships with the missions which I should say are probably better today than they have ever been. ${ }^{53}$

In the event, the MMAC was established to 'advise the Director of Medical Services on all matters relating to or affecting the medical work of Missions in the Territory'. ${ }^{54}$ Its remit echoed almost exactly the terms suggested by the Secretary of the MMC. It consisted of four state representatives, including the DMS, and four mission representatives, appointed by the MMC. The state could not reject the logic that it had helped to create. If missions were a constituent element of a national health system - a system that the missions had helped to create through their negotiations and interactions with the state through the MMC in particular - then their influence could not be ignored. By coming together, diluting the strength of the individual, missions had created a sector that could wield significant power through collective action and identity. The colonial state was not beholden to, or subjugated by, missions in the medical sphere. Indeed, missions had themselves entered a state of increased dependence upon the state as a consequence of their increased access to and influence in the Medical Department. And that mutual dependence also characterised the emergent health system: dependent upon two distinct partners working together, each helping to counteract the weaknesses of the other, and based upon actors who, ultimately, were outsiders and subject to power dynamics in the communities in which they operated, which meant they could never truly claim to be sanctioned by or reflect local demands, needs and wants. 


\section{Conclusion}

The health system created by the partnership of colonial state and mission providers, the mix of public and private (voluntary) provision, would last until the nationalisations of the $1970 \mathrm{~s},{ }^{55}$ and then re-emerge from the late 1980s onwards, when many churches were given back control over the medical facilities they had once operated as missions. At the moment of independence, missions contributed hugely to the official welfare services provided for directly and indirectly by the colonial state. In 1961, missions provided 8,350 beds in hospitals and clinics, compared to just over 7,000 under the direct control of the Medical Department. In that year missions treated 152,298 in-patients, and over 4.5 million out-patients. Government services treated only slightly more: 160,941 in-patients and 4.9 million out-patients. Six years later, at the time of the publication of the Arusha Declaration and the formal adoption of Ujamaa, missions still had over 11,000 beds and were treating 6.3 million out-patients (compared to the state's 7,890 beds and 9.9 million out-patients). ${ }^{56}$ As this chapter has sought to demonstrate, 'colonial medicine' in Tanganyika was varied, complex and functioned as a public-private partnership in which missions were formal, recognised partners in the delivery of healthcare to Africans across the territory. However, the construction of this model of healthcare delivery required missions to conceptualise themselves as belonging to a clearly designated 'sector'. From the mid-1930s, in partnership with the colonial state, which saw the advantages of cooperating with missions as an organised collective rather than atomised individuals, missions constructed institutions which would bind them together in facing the state.

In terms of the health sector, this set in train the slow formalisation of a partnership between the state and the voluntary (mission) sector that extended government regulation over mission facilities, but at the same time gave mission representatives a greater and more powerful voice within the administration. Mission hospitals and clinics had dominated healthcare in the rural areas since the late nineteenth century. With the establishment of the TMC and MMC, the engagement with the Medical Department that followed and the gradual extension of grants-in-aid to medical mission, they were transformed into a formal, albeit distinct, part of colonial health service provision in Tanganyika. This story has importance beyond what it tells us about colonial medicine, however. Looking beyond the importance of constructing a fuller narrative of the multifaceted constitution of 'colonial medicine' in Tanganyika, the emergence of the mission sector as a non-state voluntary provider of welfare services also has implications 
for post-colonial history. Firstly, it raises questions about analyses that see the period of the 1980s as critical in shifting from a public to private sector model of service delivery (in particular, as much of the literature suggests, based upon the non-governmental organisation (NGO)). The story of national ownership of public services in Tanzania is a complex one but, in the sense of full nationalisation, it is also a short one. Effectively by the 1930s, and formally with the passing of the 1948 Medical (Grants-in-Aid to Missions) Regulation, healthcare services in Tanganyika were a public-private hybrid: largely funded by the state, provided by a partnership between public and voluntary actors. The encroachment of NGOs into the public space from the 1980s was, then, not something new, but a recasting of older forms of delivery of public goods. It rested upon a different set of ideological foundations, but was based within and upon a voluntary sector space that had been created in the colonial period.

Secondly, the establishment of a 'mission sector' in welfare provision and development intervention leads us to question accounts of the 'voluntary sector' that exclude, marginalise or completely ignore missions. As this chapter has shown, missions were not just part of the creation of this sector, but its originators and first actors. The development of the sector since independence (in which faith-based organisations have continued to play a major part) has evolved in new ways and in response to newly emerging impulses. But the sets of relationships with the state, with informal voluntary actors (those which have not been officially recognised and drawn into formal channels and structures), with international actors and with the communities in which they undertake interventions, were first cast and subsequently shaped by missions in the colonial period. Any account and history of voluntary action in sub-Saharan Africa must recognise this.

Finally, the chapter has asked questions of how we understand colonial welfare policies and services. The easy assumption that welfare was simply a con, softening the hard blow of colonial occupation, becomes harder to maintain when one looks to the diversity of actors engaged in welfare provision. Missions were never simply agents of Empire, and their relationship with imperial aims varies between missions and individual missionaries, and across time and place, to create a highly complex set of interactions and relations. That is not to deny the cynical opportunism, economic strategic thinking and highly unequal power relationships and racialised stereotypes that underlay much of colonial welfare. But we cannot assume that what drove the Medical Department in, say, early 1950s Tanganyika was reflected in the views espoused by all missions engaged and employed by that state. Much has been written on the provision of public goods in post-colonial Africa. 
Those debates also need to be had for the colonial period, allowing for a grander narrative of welfare service provision in Africa that transcends colonial boundaries and considers all influences and impulses that created and shaped welfare and social development.

\section{Notes}

1 R.M. Titmuss, The Health Services of Tanganyika: A Report to the Government, London, Pitman Medical Publishing Co., 1964, p. 1

2 M. Turshen, 'The Impact of Colonialism on Health and Health Services in Tanzania', International Journal of Health Services, 7, 1977, pp. 7-35

3 T. Ranger, 'Godly Medicine: The Ambiguities of Medical Mission in Southeastern Tanzania, 1900-1945', in S. Feierman and John M Janzen (eds.), The Social Basis of Health and Healing in Africa, Berkeley, University of California Press, 1992, p. 257

4 David Hardiman, 'Introduction', in David Hardiman (ed.), Healing Bodies, Saving Souls: Medical Missions in Asia and Africa, Amsterdam and New York, Rodopi, 2006, p. 20

5 Ana Madeira, 'Portuguese, French and British Discourses on Colonial Education: Church-State Relations, School Expansion and Missionary Competition in Africa, 1890-1930', Paedagogica Historica, 41, 1/2, 2005, p. 38

6 Colonial claims on this can, however, be contested. See Michael Jennings, " "Healing of Bodies, Salvation of Souls"': Missionary Medicine in Colonial Tanganyika, 1870s-1939', Journal of Religion in Africa, 38, 2008, pp. 27-56

7 Tanzania National Archive (TanNA) 450 692. V. 1 Church Missionary Society, 'Medical Work in the Diocese of Central Tanganyika', report to Medical Department, 13 October 1936

8 Michael Jennings, "A Matter of Vital Importance": The Place of Medical Mission in Maternal and Child Healthcare in Tanganyika, 1919-39', in David Hardiman (ed.), Medical Missionaries in India and Africa, Amsterdam and New York, Rodopi, 2006, pp. $227-50$

9 TanNA File 712 Shinyanga District Annual Report 1926, pp. 29-30

10 TanNA File 712 Shinyanga District Annual Report 1926, p. 30

11 TanNA File 712 Shinyanga District Annual Report 1931, p. 37. Although a Native Authority institution, the maternity home had been set up and was run by Dr Maynard. It therefore functioned in effect as a mission medical service. For more details about the Africa Inland Mission's maternity clinic, see Jennings, 'Missions and Maternal and Child Health Care'.

12 TanNA 450692 v.1 UMCA, 'The Medical Work of the UMCA in Masasi Diocese'

13 Tanganyika Government, Report on Health Services 1959: vol. II (Statistics and Technical Papers), Dar es Salaam, Government Printer, 1960, pp. 15-16, 21. Around 1.7 per cent of out-patients in government facilities were Asian or European.

14 Edwin W. Smith, The Christian Mission in Africa: A Study Based on the Proceedings of the International Conference at Le Zoute, Belgium, September 14th to 21st, 1926, London, International Missionary Council, 1926, p. 120-1

15 TanNA 21247, v.1 Bishop of Masasi, Letter to Missions, 5 November 1937

16 TanNA 21247, v.1 Bishop of Masasi, Letter to Missions, 5 November 1937

17 TanNA 21247 v.1 Chief Secretary (?) note of interview, 24 December 1932

18 Michael Jennings, 'Common Counsel, Common Policy: Healthcare, Missions and the Rise of the "Voluntary Sector" in Colonial Tanzania', Development and Change, 44, 4, 2013, pp. 939-63

19 TanNA 21247 v.2 TMC Minutes, 12-14 May 1948

20 TanNA 24848 Director of Medical Services to the Chief Secretary, 25 February 1937

21 TanNA 450692 v.1 Secretary Berliner Mission to Director of Medical Services, 6 July 1936

22 TanNA 450692 v.1 Muller, 'Medical Mission and its Relations to Government'; the 


\section{BEYOND THE STATE}

document is undated and no author is mentioned, but it is the paper mentioned in the agenda of the TMC meeting, 9-11 July 1936 (TanNA 21247 v.1), where Dr Muller is named as the author.

23 TanNA 450692 v.1 Director of Medical Services to Chief Secretary, February 1937

24 TanNA 10721 v.5 Constitution of the Medical Missionary Committee, 1951

25 TanNA 42293 Director of Medical Services to Medical Missionary Committee (1283/1/467), cited in Minutes of Meeting of Mission Medical Committee, 22-23 January 1952. Whilst the CCT remained interested and engaged in mission-provided social services, and relations with the colonial state over their provision, it represented its Protestant members, rather than adopting an ecumenical approach.

26 TanNA 12586, v.2 W.O.H. Garman, President ACCC, 'Foreign Missions Crisis', The Voice, December 1949, p. 8

27 TanNA 12586, v.2 W.O.H. Garman, President ACCC, 'Foreign Missions Crisis', The Voice, December 1949, p. 8

28 TanNA 12586, v.2 Rev. Maynard to Rev. R.T. Davis, General-Secretary African Inland Mission, 20 March 1950. Interestingly, in describing the CCT, Maynard was keen to stress 'the [CCT] is a local organisation having no official connection with any other organisation outside itself, not even with the [Christian Council of Kenya]'.

29 TanNA 21247, v.1 Chief Secretary to Governor (?), 16 December 1932

30 TanNA 21247 v.1 Chief Secretary (?) note of interview, 24 December 1932

31 TanNA 450692 v.1 Minutes of the Meeting of the Medical Committee of the Tanganyika Missionary Council, 16 September 1937

32 TanNA 24848, UMCA to MMC Members, 18 June 1938

33 TanNA 450692 v.1 Minutes of the Meeting of the Medical Committee of the Tanganyika Missionary Council, 16 September 1937

34 TanNA 24848 Director of Medical Services to Chief Secretary, 14 October 1937, p. 2

35 TanNA 21247 v.2 Tanganyika Missionary Council Minutes, 12-14 May 1948

36 TanNA 42293 Miss Phillips (Secretary MMC) to Member for Social Services, 29 July 1952

37 TanNA 21247 v.2 Chief Secretary (G.R. Sandford), to Secretary, Tanganyika Missionary Council (Rev. Canon R. Banks, Church Missionary Society Kilimatinde), 14 September 1944

38 TanNA 21247 v.2 Chief Secretary (G.R. Sandford), to Secretary, Tanganyika Missionary Council (Rev. Canon R. Banks, Church Missionary Society Kilimatinde), 14 September 1944

39 TanNA 42300 Minutes of meeting of Medical Grants-in-Aid Committee, 12 January 1950

40 TanNA 450692 v.1 Government grants to missions for 1936 taken from Director of Medical Services to Chief Secretary, 10 August 1937; government expenditure for 1936 taken from Government of Tanganyika, Annual Report of the Medical Department, 1945, Dar es Salaam: Government Printer, 1947, p. 24

41 TanNA 10721 v.1 Secretariat Minutes, 27 June 1927; 17 November 1927

42 TanNA 24848 Secretariat Minutes, Director of Medical Services, 25 August 1937

43 TanNA 24848 Secretariat Minutes, 27 February 1937

44 TanNA AN450 178/3 Secretariat Minute, Director of Medical and Sanitary Services, 4 December 1933

45 TanNA 24843 Director of Medical Services, Cooperation with Missions, memorandum, 1937

46 TanNA AN 4501179 Director of Medical Services (P.A.T. Sneath), 'Post-War Development - Medical Department', September 1943, pp. 2-3

47 Government of Tanganyika, Annual Report of the Medical Department 1956, Dar es Salaam, Government Printer, 1957, p. 37

48 TanNA 42300 Miss Phillips, Medical Missionary Council, to Director of Medical Services, 13 August 1952

49 TanNA 42300 B. Leechman, Member for Social Services, to Director of Medical Services, 26 September 1952 (emphasis in the original) 


\section{THE HEALTH SYSTEM IN COLONIAL TANGANYIKA}

50 TanNA 42300 B. Leechman, Member for Social Services, to Director of Medical Services, 26 September 1952

51 TanNA 42300 Director of Medical Services to Member for Social Services, 16 September 1952

52 TanNA 42300 Director of Medical Services to Member for Social Services (B. Leechman), 15 November 1952

53 TanNA 42300 Director of Medical Services to Member for Social Services (B. Leechman), 15 November 1952

54 TanNA 42300 Tanganyika Gazette, 19 December 1952

55 Nationalisation of the health system never amounted to much more than the government taking over a few mission hospitals, many of which were soon returned to their original owners.

56 Tanganyika Government, Medical Department Annual Report, 1961, vol. II, Dar es Salaam, Government Printer, 1962, and Medical Department Annual Report, 1967, vol. II, Dar es Salaam, Government Printer, 1968 